\title{
THE FATE AND EFFECTS OF TRANSFUSED SERUM OR PLASMA IN NORMAL DOGS
}

\author{
By WILLIAM METCALF 1,2 \\ (From the Department of Surgery, Yale University School of Medicine, New Haven)
}

(Received for publication August 19, 1943)

\section{INTRODUCTION}

Since the recognition of the primary importance of restoring circulating blood volume in the treatment of peripheral circulatory collapse or "surgical shock," the search has been made for easily available substitutes for whole blood. Among the substances tried are solutions of crystalloids, gum acacia, or ascitic fluid, blood serum, and plasma. In the past few years, attention has centered almost exclusively on the use of plasma and serum. This is because they most nearly approach whole blood in physiological characteristics, obviate the necessity of cross-matching, and can readily be preserved for future use either in the original form, partially concentrated, or in the dry lyophile state.

The use of serum or plasma for restoring circulating volume is, of course, based on the osmotic effect of the proteins supplied. Volume gain will therefore be determined by the extent to which the protein provided is held in the vascular compartment. That, under various circumstances, protein may be rapidly removed has been shown by a number of experimental observations made within the past several years. Thus, Sibley and Lundy (1) at the Mayo Clinic found that 24 hours after a $500 \mathrm{cc}$. transfusion, the increase in circulating volume of patients accounted only for the added red blood cells, and that the added plasma of the transfusion had apparently disappeared from the circulation. Marriott and Kekwick (2) found similar results in transfusing anemic patients. Boycott and Oakley (3) and Krumbhaar and Chanutin (4) made the same observation on dogs. Freeman and Wallace (5) found that protein given as lyophilized serum was retained for 3 hours, but had disappeared in 24. Since the work reported

1 This work was planned with the help of Dr. S. C. Harvey and Dr. P. B. Price and was done when the author was Harvey Cushing Memorial Fellow in Surgery, 1939-40.

2 Now 1st Lieutenant, M.C., A.U.S. in the present paper was done, both Beattie $(6,7)$ and Scharpey-Schafer and Wallace (8) have indicated that transfused plasma protein may leave the vascular system. J. D. Robertson (9), of the Middlesex Hospital in London, did comparative studies on the intravenous use of crystalloids, gum acacia, and serum in cats, and found, contrary to expectation, that the serum disappeared from the blood stream about as rapidly as did solutions of saline or glucose. Price and Metcalf (10), in the Hunterian laboratory at Hopkins, produced acute anoxia in dogs by removing red cells from the circulation, and, in order to maintain the normal circulating volume, introduced plasma in amounts corresponding to the volume of red cells removed. However, at the end of 6 to 8 hours, the circulating blood volume corresponded only to the original volume minus the volume of red cells removed. The volume of plasma which had been introduced to make up the difference had disappeared from the circulation.

In view of these observations and in view of the increasing clinical use of various types of human protein solutions (normal, concentrated, or lyophilized serum and plasma), and because of the great immediate importance of the subject in connection with the war, it was thought that a quantitative study of the effects of protein transfusions would be both interesting and timely. The experiments reported in this paper were therefore set up to establish a base-line on intact animals of the effects of the transfused protein solutions on the plasma and red cell volumes, total serum protein, protein concentration, blood pressure, kidney function, etc., and also to determine the fate of the water and protein transfused. The establishment of this base-line would simplify further quantitative work on the effects of protein transfusions in trauma, hemorrhage, burns, and other disturbances causing peripheral vascular failure. 


\section{METHODS}

The dye method of Gibson and Evelyn (11) was used to determine plasma volume. The plasma volumes and protein concentrations were determined before and at given intervals after the transfusion. By multiplying the two together, the total protein at these points was found. Knowing the plasma volume and the relative volume of blood cells (measured by hematocrit), the total blood volume and the volume of red cells at these points could also be calculated. Thus, the effects on the circulating blood and its constituents of the addition of a known volume of plasma or serum containing a known amount of protein could be determined.

The experiments were performed on fasted mongrel stock dogs weighing 3 to $12 \mathrm{kgm}$. They were anesthetized with nembutal $35 \mathrm{mgm}$. per $\mathrm{kgm}$. and the anesthesia reinforced with $10 \mathrm{mgm}$. per $\mathrm{kgm}$., as necessary. The bladder was catheterized, and the urine collected in 4 batches; the first during the control period and the remaining 3 in approximately equal periods for the duration of the experiment after the protein transfusion. The carotid or femoral artery and accompanying vein were then exposed aseptically (the animals were used once or twice again later) and the artery cannulated. Connected to the cannula through one limb of a three-way stopcock was a mercury manometer recording mean blood pressures and a system which prevented clotting by feeding isotonic sodium citrate slowly into the cannula at a pressure slightly above the mean (usually no more than 4 to $5 \mathrm{cc}$. were used during an experiment). Blood specimens were taken from the cannulated artery by the use of two $5 \mathrm{cc}$. Luer-Lok syringes, one dry and one containing $0.5 \mathrm{cc}$. of 2.5 per cent sodium citrate, attached to a second stopcock fitting the open end of the first. By drawing about $5 \mathrm{cc}$. of blood into the syringe containing the citrate, the terminal portion of the artery and the stopcock-cannula system were cleared of stagnant blood. The specimen for the determinations was then taken with the dry syringe and the citrated blood in the first syringe was returned to the circulation. This method allowed accurately measured specimens, representative of the circulating blood, to be obtained quickly at any given moment and without any hemolysis or dilution from the blood pressure system (12).

After cannulating the artery, 3.0 to $5.0 \mathrm{cc}$. of a 0.10 per cent solution of the dye T 1824 was given intravenously. The following hour served as a control period during which the normal values for plasma, red cell, and total blood volumes, dye disappearance curve, protein concentration, hematocrit, hemoglobin, mean blood pressure, and rate of urine secretion were determined. Five and sometimes 6 blood samples were taken during this period, at 10-minute intervals, to ensure a fairly accurate determination of the rate of dye disappearance and of the plasma volume. Following this, the particular protein solution being tested, normal serum, normal plasma, or lyophilized serum 4-fold concentrated, was given into a convenient vein in a period of 10 to 20 minutes. Specimens were then taken at 15 or 30-minute intervals until the termination of the experiment. At this point, the volume was again determined by a reinjection of another $3.0 \mathrm{cc}$. of dye.
The specimens withdrawn, 4.5 cc. each, were divided into two portions, $2.5 \mathrm{cc}$. under oil for serum, and $2 \mathrm{cc}$. into bottles containing dry ammonium and potassium oxalate mixture. The serum from the clotted specimen after centrifuging was used for the measurement of the dye concentration, serum protein concentration, nonprotein nitrogen, and chlorides. Blood cell volumes and hemoglobins were determined on the oxalated specimen.

The color intensities of the solutions containing dyes were measured by means of the micro unit of the Evelyn photoelectric colorimeter $(13, a)$. The sera were analyzed for proteins in duplicate by the falling drop method of Barbour and Hamilton $(13, b)$, and the concentrations were calculated by the formula of Weech (14). The cell volumes were determined by the use of Wintrobe hematocrit tubes, and the hemoglobins, with the photoelectric colorimeter. The non-protein nitrogen and chloride of serum and the nitrogen and chloride of urine were measured by the routine clinical laboratory methods.

The serum and plasma used were obtained by bleeding large healthy stock dogs. For the plasma, $10 \mathrm{cc}$. of 2.5 per cent sodium citrate were used for each $100 \mathrm{cc}$. of blood withdrawn. The 4-fold concentrated serum was made by the addition of $25 \mathrm{cc}$. of sterile distilled water to the powder representing $100 \mathrm{cc}$. of normal serum. ${ }^{2}$

\section{CALCULATIONS AND GRAPHIC REPRESENTATION}

The primary calculation of volume was made by the usual method from the extrapolated dye concentration value (Lo) and the factor for the dye solution used. Serial determinations of plasma volume after the primary determination were usually made by multiplying the original volume (minus the amounts removed in sampling) by the ratio of the expected dye concentration to the actual dye concentration at the given times wanted. The actual dye concentrations of the specimens were, of course, determined with the colorimeter. The expected dye concentrations are usually read off, for the given intervals of time, on a graphic logarithmic projection of the original disappearance curve. However, this latter procedure was not accurate enough for the purposes of these experiments, since the very possible small error of 4 to 5 per cent in drawing the curve through the original 5 dye determinations would introduce an error of 24 to 30 per cent at the end of 5 hours in the expected dye concentration values and therefore an equal error in the volume calculations.

A method of calculation was therefore worked out whereby the over-all dye disappearance rate

\footnotetext{
2 Kindly supplied to us by Dr. John Reichel of the Sharp and Dohme laboratories.
} 
could be determined for the whole period of the experiment from the point of the original volume determination to the point of the final volume redetermination by the dye reinjection. The rate of dye disappearance in percentage per hour is given by the formula,

$$
100\left(1-\sqrt[t]{\frac{\text { mgm. dye remaining }}{\text { mgm. dye injected }}}\right)
$$

where $t$ is the time in hours elapsed. The value for the known amount of dye given is corrected for the amount of dye removed in the 15 to 20 specimens. The amount of dye remaining is calculated from the plasma volume determined at the end of the experiment by a reinjection of dye and the concentration of dye in the plasma as determined on the specimen taken a moment before the reinjection.

Knowing the rate of dye disappearance, $R$, and the actually determined dye concentration at any point, $C$, the expected dye concentration at the end of a given time interval, $t$, will then be $X\left(100-R^{t}\right)$. The successive serial determinations are then carried out each from the one immediately preceding, as in the following example. Given a plasma volume $V$, to determine volumes $V_{1}$ and $V_{2}$, at time intervals $t_{1}$ and $t_{2}$, when the dye concentrations read on the colorimeter are $C, C_{1}$, and $C_{2}$ and the volumes of plasma removed by sampling are $s$ and $s_{1}$. Then

and

$$
V_{1}=(V-s) \times \frac{C\left(100-R^{t_{1}}\right)}{C_{1}}
$$

$$
V_{2}=\left(V_{1}-s_{1}\right) \times \frac{C_{1}\left(100-R^{t_{2}}\right)}{C_{2}} .
$$

These calculations, although somewhat complicated, were made relatively easy by the use of logarithms.

Having determined the plasma volumes and knowing the relative cell volumes, the total blood volumes and red cell volumes are calculated. The changes in size of the individual red cells were deduced from the changes in mean corpuscular hemoglobin concentration

$$
\text { ( } \left.\frac{\text { Grams hemoglobin per } 100 \text { cc. } \times 100}{\text { Cell volume per cent }}\right) \text {. }
$$

The average of the 5 or 6 determinations of the control period was taken as normal and the ratio of that to the values determined during the experimental period, expressed as per cent, indicated the change in size.

For purposes of comparison, the results were all calculated on a percentage basis and are thus shown graphically in the figures reproduced. The values for plasma volume, total plasma protein, volume of red blood cells, and plasma protein concentration just prior to the transfusion are taken as 100 per cent. The values for blood pressure, chlorides, and N.P.N.'s are recorded in the usual terms. The percentage change from the control period in the rate of urinary excretion is given as a horizontal line, since the rate was determined by dividing the volume produced in a relatively long period of time ( $\frac{1}{2}$ to 1 hour) by that time. The line therefore represents the average rate for the period. The salient data in each experiment are given in Table I.

\section{RESULTS}

\section{A. The fate of the transfused protein}

The most striking phenomenon observed in these experiments was that the transfused protein or its circulating equivalent disappeared from the blood stream (Figures 1, 2, and 3). As shown below, this could not be accounted for in the urine as whole protein or its metabolic products. Presumptive evidence that the protein was not immediately stored or broken down in the liver was obtained when serum was transfused directly into the portal system of a dog. Here, the protein appeared in the general circulation in approximately the amount transfused and then disappeared from the blood stream at about the same rate as in the other experiments (Experiment 3). The possibility that the donor protein might have some individual specificity, and was therefore being taken up in the recipient dog as a foreign substance, was also entertained. However, when dogs were transfused with their own serum, obtained from them a day or two before and refrigerated until used, the results were the same as in all the other experiments (Experiments 7 and 8).

Striking, too, is the fact that the added protein, or its equivalent, disappears from the blood stream at a constant rate. The rate varied from animal to animal and ranged between 0.5 and 3.8 grams per hour. Calculated in relation 


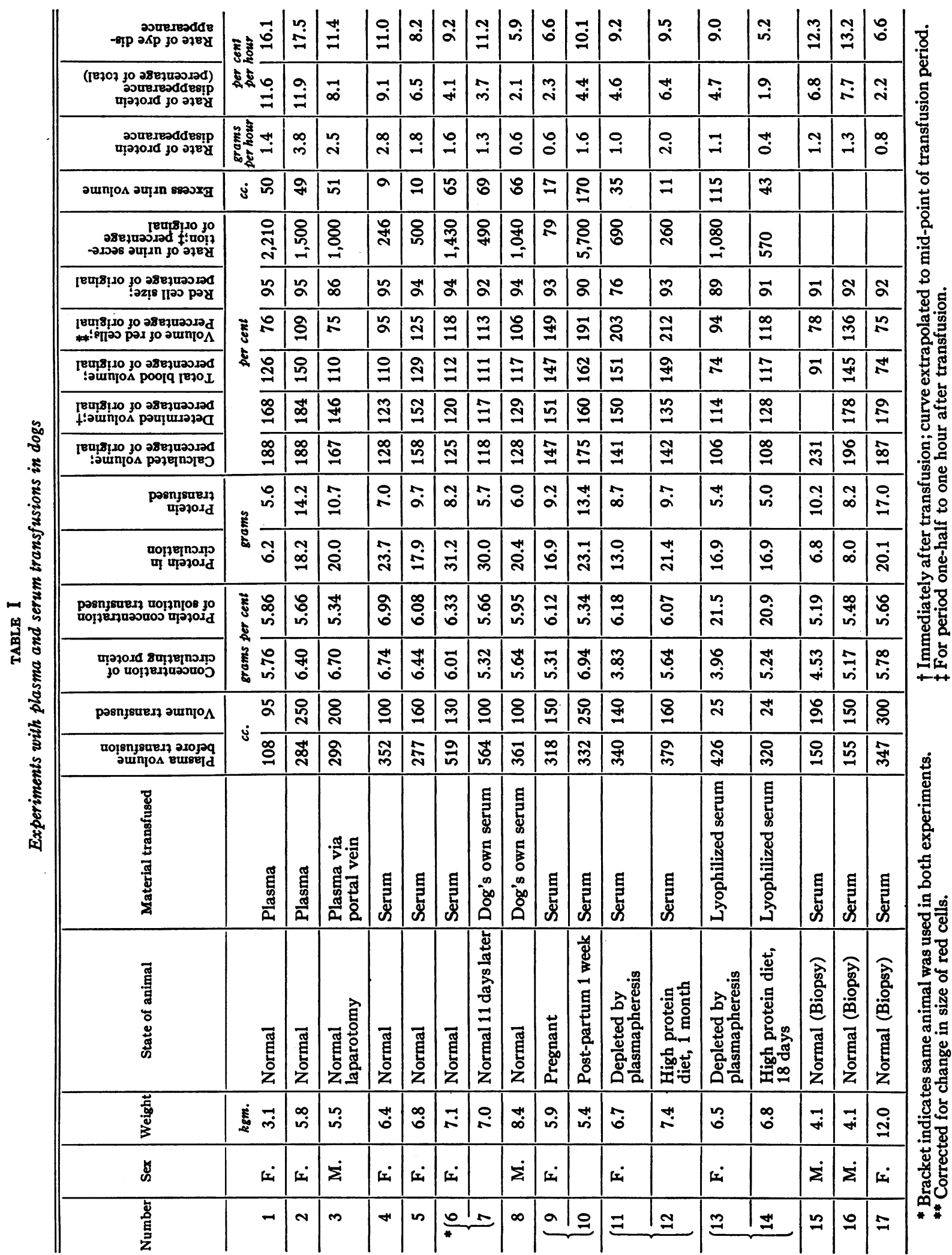



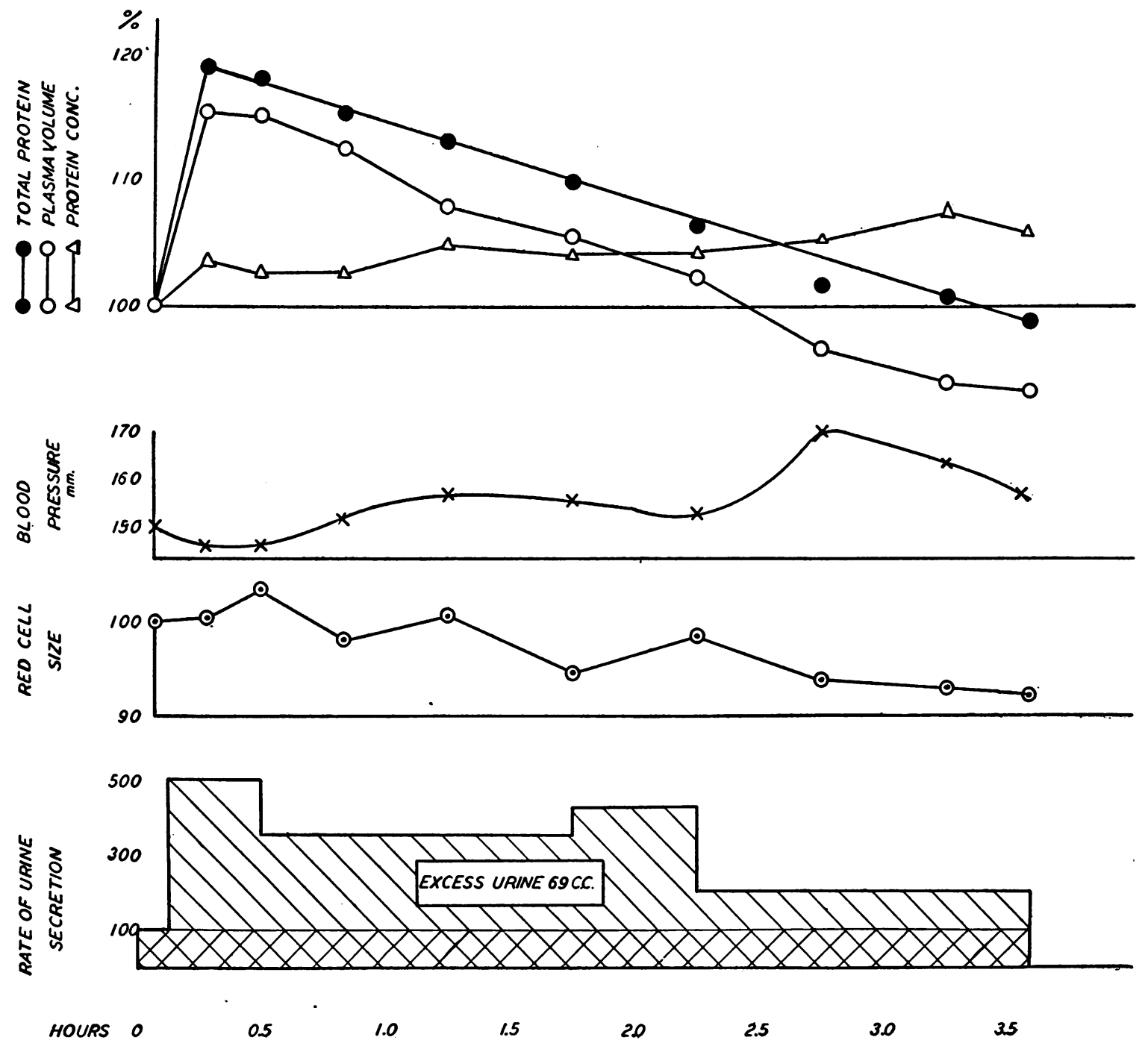

Fig. 1. One Hundred cc. of Normal Serum to a Normal Dog (Experiment 7)

Note the reciprocal relationship between the protein concentration and plasma volume. Note too the increase in gradient of plasma volume change in the two intervals when the blood pressure rose.

to the total amount present, the rate ranged between 2.1 and 11.9 per cent per hour, with an average for the series of 6 per cent per hour. This rate is completely independent of the amount given as is shown by the fact that no correlation could be established between amounts given and rates of disappearance for the whole series of experiments (Table I). Neither was any correlation apparent between rate and volume transfused, surface area, depth of anesthesia, general condition, or age of the animal.

Very interesting, however, is the finding that there is an excellent degree of correlation $(r=0.88 \pm 0.036)$ between the rate of protein disappearance (in percentage of total per hour) and the rate of dye disappearance (Figure 6). Whether the rate of protein disappearance was logarithmic or linear could not be determined from the experiments, since for the magnitude of the percentage change per hour, the logarithmic and arithmetic projections both gave straight lines. Fortuitously, the experiments in which the rate may have been high enough to show a difference in the projection were done early in the work and only carried through for an hour or two (Experiments 1 and 2). Since the rate 

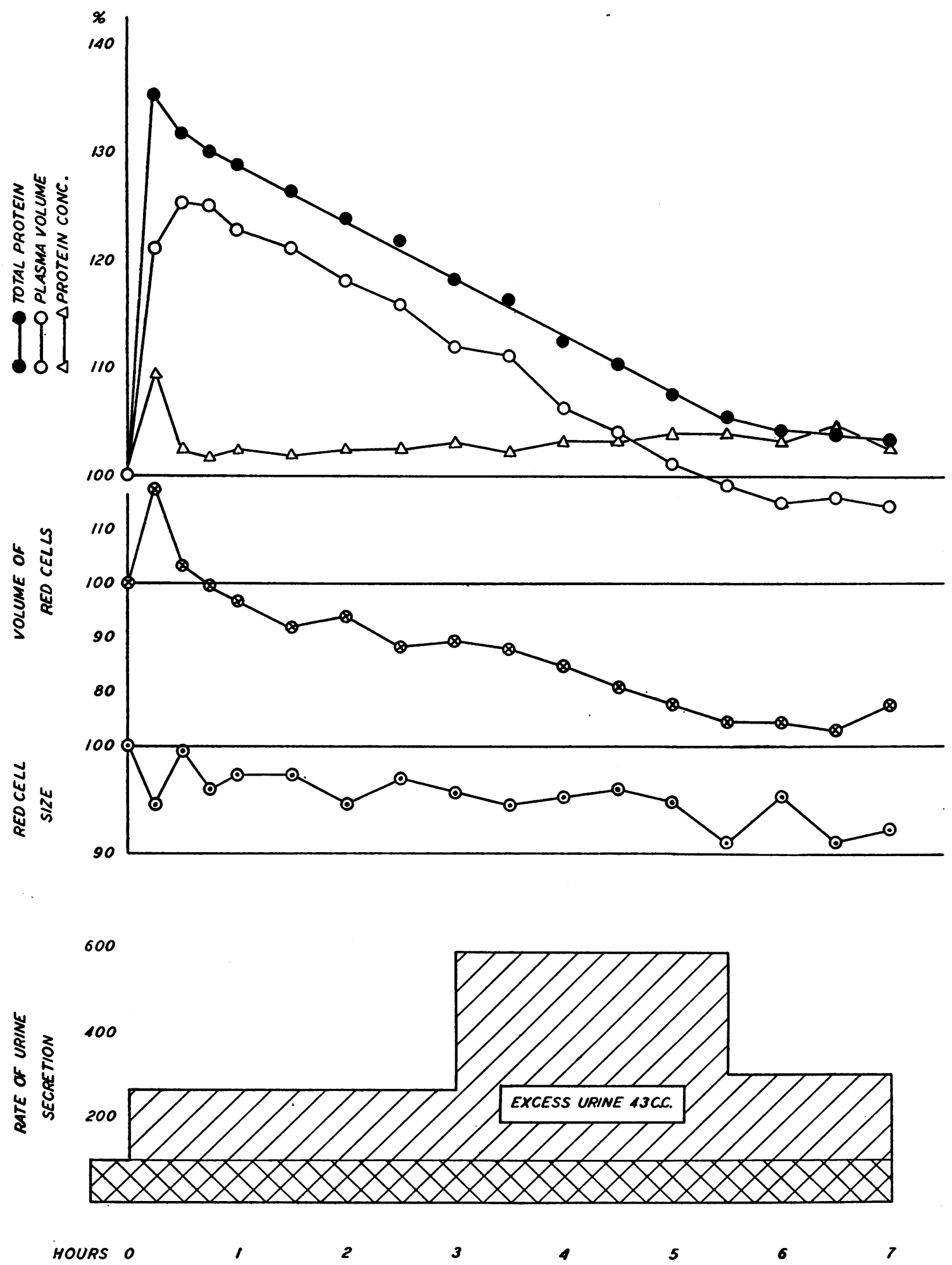

Fig. 2. Twenty-Four cc. of Lyophilized Serum (4-Fold concentrated) to a Normal Dog (Experiment 14)

The peak in the total protein curve represents 1.1 grams of protein coming into the circulation from extravascular sources and the hump in the plasma volume curve represents fluid coming into the circulation. (The blood pressure had dropped to about $60 \mathrm{~mm}$. during the transfusion but came back to normal in the next 20 minutes.) The plasma protein and plasma volume return to normal in $5 \frac{1}{2}$ hours. Note that about 25 per cent of the volume of red cells (even with the correction for the change in size) has disappeared from the circulation. 

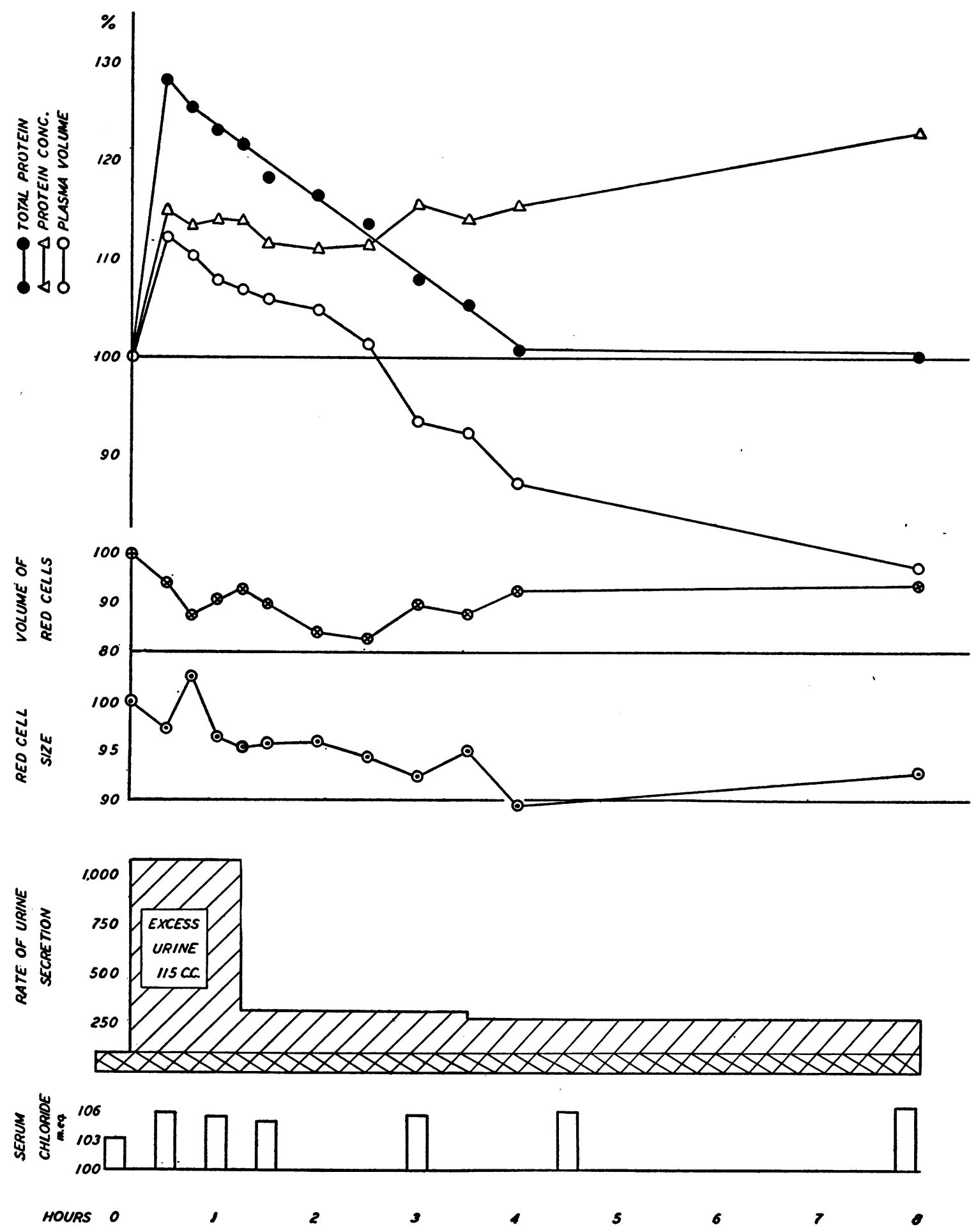

Fig. 3. Twenty-Five cc. of Lyophilized Serum (4-Fold concentrated) to a Protein Depleted Dog (EXPERIMENT 13)

The total plasma protein returned to normal in about 4 hours and remained at that level while fluid continued to leave until the plasma volume was reduced to about 80 per cent of the original, with a resultant increase of the protein concentration. The urine volume secreted was almost 5 times the volume transfused. 
of dye disappearance is logarithmic, the implication of the high degree of correlation is that the protein disappearance rate is logarithmic too.

To determine if the rate were dependent on the state of the "protein reserves," two animals were kept on a protein-free diet and depleted of protein to near edema levels by the plasmaphoresis method of Melnick and Cowgill (15). They were then transfused with both normal and lyophilized serum. The rates of disappearance in these two dogs were of the same order of magnitude as the average for the whole group and certainly not any greater. The protein levels and "reserves" were then brought back to normal in a few weeks by feeding a high protein diet after which the experiments were repeated. Here, too, the rate of disappearance was about the same and not any slower than when these animals were in a depleted state (Experiments $11,12,13$, and 14).

The protein that leaves the blood stream is not excreted as such by the kidneys. Each of the 4 or 5 specimens of urine in each experiment was tested for albumin and in only 2 or 3 did a few specimens show just a trace. Neither is it excreted in the form of non-protein nitrogen. If all the excess non-protein nitrogen in the urine (the amount over and above that which would have been found had the rate of nitrogen excretion in the control period held throughout the experiment) is considered to have originated in the transfused protein, then for the group of experiments, only an average of 8 per cent of the amount given is so excreted. Of course, much or all of the latter may have been due to increased body protein metabolism because of increased muscular activity. The dog is quietest when in deepest anesthesia during the control period, just after the nembutal is given, and of ten during the experimental period, he shivers or struggles. There was also no increase whatever over the control levels in the serum N.P.N. in the 5 experiments in which it was determined at hourly intervals after the transfusion.

Immediate metabolism and excretion having been ruled out, the possibility of deposition of the added protein in a specific organ or tissue of the body suggested itself. In 3 experiments, liver, muscle, kidney, and intestine biopsies were taken before and 8 to 10 hours after a rather large serum transfusion. The specimens were then analyzed for water, chloride, and nitrogen. In these experiments, the amounts of water and protein remained remarkably constant but there was a slight drop in the chloride. If the protein had been taken up by any single organ, a determinable difference might have been found. However, the absence of a significant change suggests that the protein taken up was evenly distributed throughout the body. This would not be detectable by ordinary analytical methods, since the amount given averaged no more than 0.8 per cent of the total body protein. (The latter was calculated as 18 per cent of body weight on the basis of the analysis of animals done by Harrison, Darrow, and Yannett (16).)

Not only does protein leave the blood stream but a few of the experiments suggest the interesting possibility that protein may come rapidly, perhaps in limited amounts, into the blood stream from extravascular sources. This was seen in 3 experiments in which a sharp drop in blood pressure occurred during or immediately following the transfusion. In these 3 , the total protein rose above the level determined after the transfusion and this rise amounted to 0.6, 0.7, and 1.1 grams, respectively. In none of the other experiments was a subsequent value for total protein greater than that determined immediately after the transfusion.

\section{$B$. The fate of the transfused fluid}

The transfused fluid, that is, the plasma considered without its protein, also leaves the blood stream and the plasma volume returns toward normal. This occurs in from 3 to 8 hours, depending on the rate at which the fluid leaves and on the amount given (Figures 1, 2, and 3). The rate of plasma volume change (fluid loss) is in almost all cases more rapid than the rate of protein loss. A concomitant upward trend in the plasma protein concentration results, but the latter did not go above 110 per cent of the original value except in one experiment in which lyophilized serum was used (Figure 3).

Although the rate of fluid loss is fairly constant, it varies from moment to moment within certain limits and causes an immediate reciprocal change in the protein concentration. The 
latter goes up rapidly when fluid leaves the blood stream and goes down when fluid shifts in from the tissue spaces. These momentary changes in rate of fluid loss are synchronous with variations in the blood pressure. Throughout these changes, however, the rate of protein loss remains constant (Figure 1).

There was an initial shift of fluid into the blood stream only in two circumstances. First, when there was a sharp drop in blood pressure. This occurred in 3 or 4 experiments and was probably due to an anaphylactic type of reaction, as evidenced by the appearance of transient cutaneous wheals and the return of the blood pressure to the original level within an hour or so. Second, when the concentration of the protein in the material transfused was much greater than the circulating plasma protein concentration. This occurred in the two dogs which were given lyophilized serum and in the dog whose plasma protein level was 3.83 grams per cent and which was transfused with serum containing 6.17 grams per cent of protein (Experiments 11, 13 , and 14).

Not all of the fluid transfused remains in the body with the protein; much of it is excreted by the kidneys. In all of the dogs, a greater volume of urine was excreted than would have been expected had the control rate of urine formation continued throughout the experiment. In 7 out of 14 experiments, the volume of excess urine was more than 50 per cent of the transfused volume. This was most striking in the two animals receiving lyophilized serum-approximately 5.5 grams of protein in $25 \mathrm{cc}$. of water. One dog secreted an excess of $115 \mathrm{cc}$. and the other, an excess of 43 cc. of urine (Figures 2 and 3 ).

The rate of urine formation ranged between 0.030 and $0.140 \mathrm{cc}$. per minute with an average for the series of $0.080 \mathrm{cc}$. per minute. This rate is tremendously increased during the first hour or so after the transfusion. It drops rapidly toward normal in the next hour or so and then approaches the control rate as the plasma volume returns to normal. The average increase for the group of experiments in the post-transfusion period was 680 per cent. The increase in rate in the post-transfusion period correlated fairly well with the percentage in-

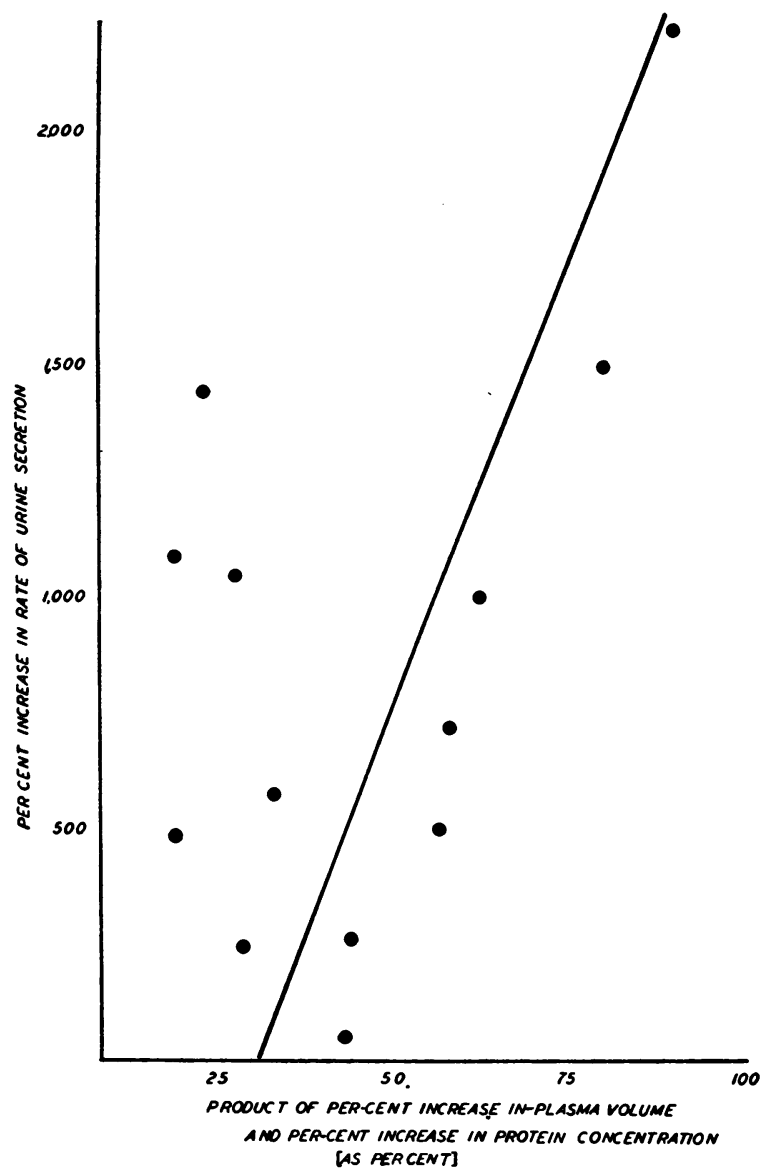

Fig. 4. The Correlation Between the Percentage InCREASE IN RATE OF URINe SECretion for the PERIOD IMmEdiately Following THE TRANSFusion AND THE Product of the Percentage Changes in Plasma Volume and Protein Concentration

This product expressed arbitrarily as per cent gave a better correlation than either the increase in volume or change in protein concentration individually.

crease in the plasma volume, induced by the transfusion.

The correlation was better when the change in protein concentration was also taken into account by multiplying the percentage volume increase by the percentage change in protein concentration (Figure 4). In those dogs where there was an initial drop in blood pressure, the diuresis occurred later in the experiment, when the pressure returned to normal. In only one dog was there a diminished rate of secretion throughout the experiment. This animal was pregnant and near term. Interestingly enough when the experiment was repeated on this same 
dog a week or so post-partum, the rate of urinary secretion for the first hour after the transfusion was 57 times greater than that of the control period.

\section{Other effects of the transfusion}

The effects of the transfusions on circulating red cell volume were variable. In 8 of the experiments, there was a fairly marked increase, averaging about 50 per cent; in 5 , there was little or no change; and in 4 , there was a fairly marked drop, averaging about 25 per cent. In those where it increased, there was a gradual return to normal with the plasma volume; in those where the transfusion caused cells to leave the circulation, there was little or no tendency for a return to the original level (Figures 2 and 3 ). In general, the volume of red cells coming into the circulation was roughly proportional to the volume of added plasma, with the result that the percentage increase in total blood volume was approximately that of the percentage increase in plasma volume. The effect was therefore as though a volume of whole blood, approximately twice the volume of plasma, were

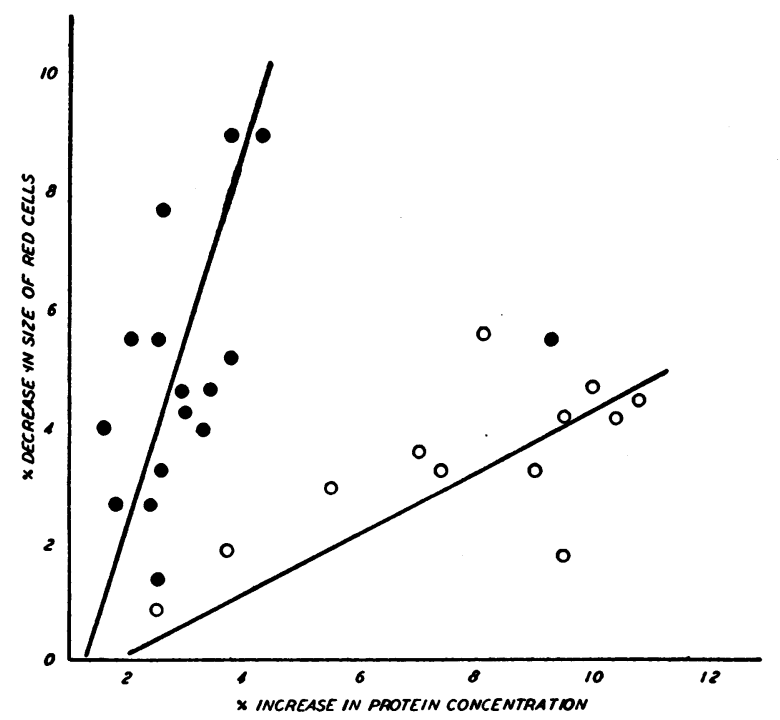

Fig. 5. The Correlation Between the Decrease in Size of the Red Cells and the Increase in Concentration of the Plasma Protein in Two of the ExPERIMENTS

The solid circles represent Experiment 7 (Figure 1) and the open circles Experiment 14 (Figure 2).

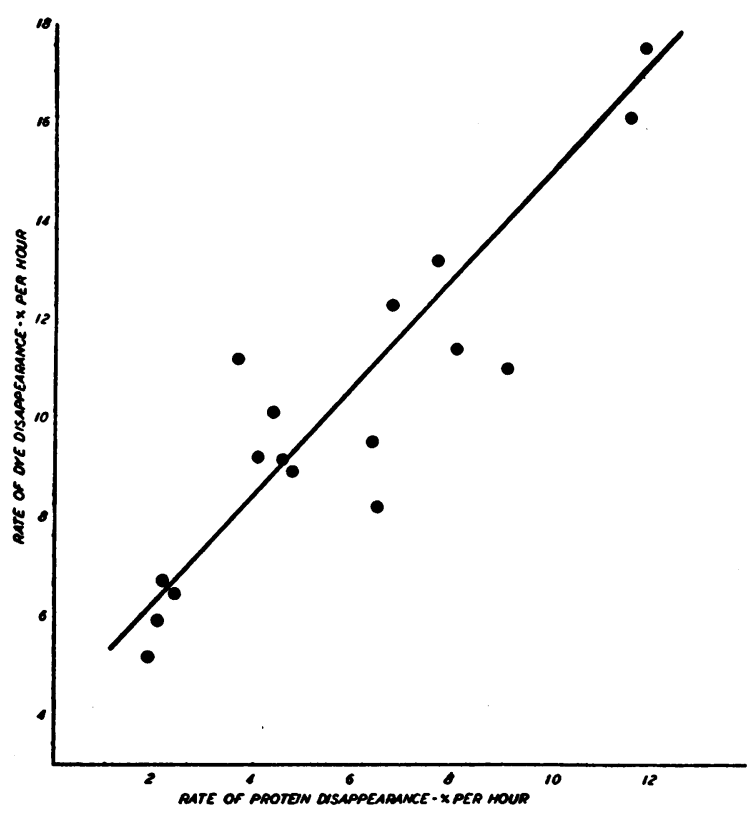

Fig. 6. The Correlation Between the Rate of Protein Disappearance (as Per Cent of Total Circulating Protein after the Transfusion) and the Rate of Dye Disappearance

given. (Compare the eighth and ninth columns of figures in the table.) Of course, where red cells left the blood stream, the net effect on the total blood volume was the algebraic summation of the volume of plasma added and the volume of red cells leaving.

Although the total volume of red cells was somewhat variable, there was a constant change in the individual red cells. They decreased slowly but progressively in size throughout the post-transfusion period (Figures 1, 2, and 3). This is shown by the fact that there was a progressive increase in the mean corpuscular hemoglobin concentration. If the ratios of the control value to the post-transfusion values are taken as a measure of this decrease in size, the maximum change noted in each experiment ranged for the series between 5.0 and 23.6 per cent, with an average for the series of 8.3 per cent. In all probability, this decrease in size of the red cell indicates a loss of water from the cell. In about half of the experiments, there was a direct correlation between the percentage decrease in size and the percentage increase in plasma protein concentration (Figure 5). 
Only two chemical constituents of the blood were studied-the serum non-protein nitrogen and chloride. Since the chloride concentration of the plasma or serum introduced was about the same as that of the circulating plasma there was of course no difference as a result of the transfusion. Where concentrated chloride was given in the lyophile experiments, there was a rise of only 2 to 3 m.eq. Excess chloride was excreted in those experiments in which there was a marked excess of urine put out and in approximately the same concentration as the control. There was nothing unusual noted in the distribution or excretion of the added non-protein nitrogen.

Finally, it should be noted that the changes in total blood volume, incident to the transfusion, caused no change in the blood pressure. The blood volume increases ranged between 10.0 and 84.0 per cent but in no single experiment was there as much as a $5 \mathrm{~mm}$. increase in the mean arterial pressure. On the other hand, neither was there a significant drop in blood pressure when the blood volume decreased by 26 per cent, as it did in 2 experiments.

\section{DISCUSSION}

On the basis of nitrogen balance studies, Whipple (17) formulated the theory that "a steady state or ebb and flow exists between the plasma proteins and a portion of cell and tissue proteins." This steady state he referred to as "a dynamic equilibrium." More direct evidence for this theory was found by Schoenheimer (18) in his studies of metabolic processes with substances labelled by isotopic atoms. The results of the experiments reported in this paper are further confirmation of this theory, since they too show that protein not only leaves the blood stream, but may also come into it from extravascular sources.

If this state of equilibrium exists between most of the tissue proteins and the plasma protein, the explanation for quantitatively little or none of the protein transfused remaining in the blood stream becomes apparent. A 10-kgm. dog would have approximately 1800 grams of tissue protein and $\mathbf{3 0}$ grams of plasma protein. Therefore, any amount added to the latter might be expected to distribute itself in approximately the ratio of 60 parts in the tissues and 1 part in the plasma. Although actually this ratio may not be of the magnitude given, such a distribution undoubtedly occurs.

This helps to explain why patients with nephrosis or nutritional hypoproteinemia do not get an appreciable increase of plasma protein, even when given large quantities of protein intravenously. It also helps to explain why in many acute pathological conditions such as trauma, burns, or acute intestinal obstruction, plasma transfusions, even if large, may only be of temporary benefit. Fine and Gendel (19) found that if in shock due to experimental intestinal obstruction, they gave even as much again or more than the original volume of plasma, there was nevertheless a subsequent drop of plasma volume of 39 per cent and the dogs died in 5 or 6 hours. Rhoads, Wolff, and Lee (20), in a study of burn patients, noted that "when large plasma transfusions were administered soon after the receipt of a burn, there was not as great a rise in plasma volume as had been anticipated and furthermore, as a rule the rise that was obtained was temporary." That plasma was not only being lost locally by exudation from the burned surface, but that a good proportion of it was simultaneously leaving the vascular system, generally seems to be the most probable explanation for these observations.

The finding that the protein which disappears from the blood stream is not broken down and excreted by the kidneys had already been made by Howland and Hawkins (21) on phlorizin diabetic dogs. They concluded that the protein was removed from the blood stream and stored in the body tissues as such or that it was only partially broken down and then rebuilt into tissue protein.

The diuresis induced by the transfusions is probably not the result of increased osmotic pressure only, since it occurred in many experiments where no increase in protein concentration was caused by the transfusion. Weech (22) also found this to be true, and showed that a diuresis could be induced by giving a volume of red cells washed free of their plasma. He therefore concluded that the increased blood volume was the stimulus for the diuresis. In these ex- 
periments, the increase in rate of secretion immediately following the transfusion was found to be roughly proportional to the increase in plasma volume and the change in protein concentration. The excess urine volume, in relation to the volume transfused, was greatest, however, in those cases where lyophilized serum was used. The possibility of causing dehydration or increasing that already existent with the use of concentrated or even normal plasma therefore should be kept in mind.

The decrease in size of the red cells also indicates a loss of water. The volume given up, however, is small in comparison to the excess volume excreted by the kidneys and the remainder of the latter must have come from extravascular sources. The correlation between the decreasing size of the red cell and the increasing protein concentration suggests that the former is due to increasing osmotic pressure. However, the change in size of the red cell is much too great to be explained on the basis of the observed change in protein concentration only, and therefore some of the electrolytic components of the plasma must have increased in concentration too. In those experiments where there was little correlation between the two, there may have been a decrease in electrolyte concentration, offsetting the effect of the increase in protein concentration.

It should be emphasized in passing that this change in size of the red cell may be one of the sources of error, and perhaps a major one, in the use of the hematocrit for the calculation of changes in total blood volume and volume of red cells, following plasma transfusions. This factor may explain many of the discrepancies noted in the literature between calculated and determined volumes of plasma and red cells on the basis of the hematocrit. Thus, the shrinkage of the red cells by 8.5 per cent (the average found in this series) will introduce a change of 15 per cent in the hematocrit and therefore an apparent discrepancy of 15 per cent between the expected and determined volume of red cells.

The exact mechanism by which the protein leaves the blood stream was not elucidated by these experiments. However, it was recently shown by Dawson (23) and Gregersen and Dawson (24) that the dye is bound to the al- bumin fraction of the protein. They concluded that "one implication ... is that the rate of disappearance of T-1824 during the first hour after the injection is a measure of the rate of exchange of albumin" (between plasma and tissues).

Since the dye leaves at a logarithmic rate and there is a high degree of correlation in these experiments between that rate and the rate of protein disappearance, the conclusion is warranted that at least the albumin fraction of the protein transfused leaves at a logarithmic rate. The rate is therefore related to the total amount present, as is true of many other biological processes. Although the determination of albumin-globulin ratios was not done, it is probable that the added globulin also leaves the blood stream, since in those experiments which were carried far enough, all of the added protein disappeared, and the total protein remaining leveled off at the original amount present.

\section{CONCLUSIONS}

1. Protein given intravenously to normal dogs, either as normal or concentrated serum or plasma, leaves the blood stream in a relatively short time.

2. The rate of disappearance of this transfused protein is constant and not related to the changes in volume or concentration caused by the transfusion or to the state of protein reserves.

3. The correlation between the rate of protein disappearance and the dye disappearance suggests that the former is logarithmic and therefore related to the total amount of protein in circulation.

4. The diuresis induced is roughly proportional to the increase in plasma volume and change in protein concentration.

5. The transfusion causes a loss of water from the red cells resulting in a decrease in their size. The latter may be an important source of error in calculations of volume change by the hematocrit.

6. These experiments offer an explanation for the observation that, in many pathological states, only temporary benefits are derived from plasma transfusions. 
7. These experiments add evidence, too, to the concept of a dynamic equilibrium between plasma and tissue proteins.

I wish to acknowledge the help of Dr. S. C. Harvey and Dr. P. B. Price in plan-ing this work.

\section{BIBLIOGRAPHY}

1. Sibley, W. L., and Lundy, J. S., The blood volume and hemoglobin after transfusion. Surg., Gynec. and Obst., 1938, 67, 490.

2. Marriott, H. L., and Kekwick, A., Volume and rate in blood transfusion for the relief of anaemia. List. M. J., 1940, 1, 1043.

3. Boycott, A. E., and Oakley, C. L., The adjustment of blood volume af ter transfusion. J. Path. and Bact., 1934, 38, 91.

4. Krumbhaar, E. B., and Chanutin, A.. Studies in experimental plethora in dogs and rabbits. J. Exper. Med., 1922, 35, 847.

5. Freeman, N. E., and Wallace, W. M., The effect of concentrated serum on plasma volume and serum protein concentration. Am. J. Physiol., 1938, 124, 791.

6. Beattie, J., Changes in haemoglobin concentration and plasma specific gravity following plasma transfusions. Brit. M. J., 1942, 1, 459.

7. Ibid., Fate of transfused plasma. Lancet, 1942, 2, 445.

8. Sharpey-Schafer, E. P., and Wallace, J., Retention of injected serum in the circulation. Lancet, 1942 $1,699$.

9. Robertson, J. D., A comparison of the interchange of the body fluids after intravenous injections of crystalloids, gum acacia, and blood-serum. Brit. J. Exper. Path., 1938, 19, 30.

10. Price, P. B., and Metcalf, W., Unpublished data (1939).

11. Gibson, J. G., and Evelyn, K. A., Clinical studies of blood volume. IV. Adaptation of the method to the photoelectric micro-colorimeter. J. Clin. Invest., 1938, 17, 153.

12. Price, P. B., Hanlon, C. R., Longmire, W. P., and Metcalf, W., Experimental shock. I. Effects of acute hemorrhage in healthy dogs. Bull. Johns Hopkins Hosp., 1941, 69, 327.

13a. Evelyn, K. A., and Gibson, J. G., 2nd, A new type of absorption cell for the photoelectric micro-colorimeter. J. Biol. Chem., 1938, 122, 391.

b. Barbour, H. G., and Hamilton, W. F., The falling drop method for determining specific gravity. J. Biol. Chem., 1926, 69, 625.

14. Weech, A. A., Reeves, E. B., and Goettsch, E., The relationship between specific gravity and protein content in plasma, serum, and transudate from dogs. J. Biol. Chem., 1936, 113, 167.

15. Melnick, D., and Cowgill, G. R., A quantitative technique for performing plasmapheresis. J. Exper. Med., 1936, 64, 865.

16. Harrison, H. E., Darrow, D. C., and Yannett, H., The total electrolyte content of animals and its probable relation to the distribution of body water. J. Biol. Chem., 1936 113, 515.

17. Madden, S. C., and Whipple, G. H., Plasma proteins: their source, production and utilization. Physiol. Rev., 1940, 20, 194.

18. Schoenheimer, R., The Dynamic State of Body Constituents. Harvard University Press, Cambridge, 1942.

19. Fine, J., and Gendel, S., Plasma transfusion in experimental intestinal obstruction. Ann. Surg., 1940, $112,240$.

20. Rhoads, J. E., Wolff, W. A., and Lee, W. E., The use of adrenal cortical extract in the treatment of traumatic shock of burns. Ann. Surg., 1941, 113, 955.

21. Howland, J. W., and Hawkins, W. B., Protein metabolism, protein interchange and utilization in phlorizinized dogs. J. Biol. Chem., 1938, 123, 99.

22. Weech, A. A., The Significance of the Albumin Fraction of Serum. The Harvey Lectures, page 57 (1938).

23. Dawson, R. A., The binding of T-1824 and structurally related dyes. Am. J. Physiol., 1943, 138, 708.

24. Gregersen, M. I., and Dawson, R. A., The disappearance of $\mathrm{T}-1824$ and structurally related dyes from the blood stream. Am. J. Physiol., 1943, 138, 698. 